\title{
Original
}

\section{Induction of Tumor Necrosis Factor-Alpha Immunoreactivity in Rat Retinal Pigment Epithelial Cells Ischemic Insult}

\author{
Dai OGINo ${ }^{1)}$, Seiji ShIOdA ${ }^{1)}$, Keiichi MiYamoto ${ }^{2)}$, Tamotsu SeKI ${ }^{3)}$, \\ Toshihiko UedA ${ }^{3)}$, Yuji KIUCHI ${ }^{4)}$, Ryohei KoIDE ${ }^{3)}$ \\ and Yasumitsu NAKAI ${ }^{1)}$
}

\begin{abstract}
Retinal pigment epithelium (RPE) plays an important role in retinal function, and may contribute to retinal degeneration via expression of specific cytokines. The retina of a four-vessel occlusion rat model was used to investigate the localization of TNF- $\alpha$ following ischemia/reperfusion, to determine whether TNF- $\alpha$ expression may contribute to retinal degeneration. At the ultrastructural level, the 2-day RPE cells were irregular in shape, and showed increased phagocytosis of rod outer segments. Immunohistochemistry demonstrated that ischemia-damaged RPE cells showed upregulation of N-methyl-D-aspartate receptor type 1 (NMDA-R1) and TNF- $\alpha$ immunoreactivity. However the first appearance of NMDA-R1 immunoreactivity preceded that of the TNF- $\alpha$ immunoreactivity. Both the NMDA-R1 and TNF- $\alpha$ immunoreactivities were decreased with time. To investigate the effect of glutamate on TNF- $\alpha$ expression, cultured rat RPE cells were treated with $1 \mathrm{mM}$ glutamate, and TNF- $\alpha$ gene expression was examined by RT-PCR. TNF- $\alpha$ mRNA expression was increased after the 4-day glutamate treatment. These results suggest that TNF- $\alpha$ is synthesized in RPE cells, and may play an important role in the development of retinal degeneration induced by ischemia/reperfusion insult at an early stage. Glutamate may induce TNF- $\alpha$ expression via NMDA-R1.
\end{abstract}

Key words : retinal pigment epithelium cells, the rat four-vessel occlusion model, immunohistochemistry, tumor necrosis factor-alpha, $\mathrm{N}$-methyl-D-aspartate receptor type 1

\section{Introduction}

Tumor necrosis factor-alpha (TNF- $\alpha$ ), an angiogenic cytokine, is a protein toxin and is thought to be a principal mediator of the manifestations of inflammation ${ }^{1)}$. TNF- $\alpha$ is widely secreted in response to invasive stimuli. In addition, TNF- $\alpha$ appears to have a variety of other functions and is expressed in virtually all cell types ${ }^{2,3)}$. Intraocular injection of TNF- $\alpha$ can induce acute uveoretinitis ${ }^{4)}$. However, the mechanism of action and localization

\footnotetext{
1) Department of Anatomy, Showa University School of Medicine, 1-5-8 Hatanodai, Shinagawa-ku, Tokyo 142-8555, Japan.

2) Department of Pharmacology, Showa University School of Medicine.

3) Department of Ophthalmology, Showa University School of Medicine.

4) Department of Pathophysiology, Showa University School of Pharmaceutical Sciences.
} 
of TNF- $\alpha$ in the retina remains unknown.

The retinal pigment epithelium (RPE), a single layer of cells around the outer circumference of the retina, is essential for homeostasis of the microenvironment of the eye. Phagocytosis is a major function of RPE cells ${ }^{5)}$ and this action is impaired in several retinal disorders. RPE cells may contribute to the development of ocular inflammation and proliferative diseases by releasing chemical modulators ${ }^{6-14)}$.

Many studies have shown that ischemic insult to the retina, which is usually induced by high intraocular pressure or retinal artery obstruction, results in degeneration of the sensory retina ${ }^{15,16)}$. Retinal degeneration also occurs in the ganglion cell layer and inner nuclear layer of the infant mouse pretreated with subcutaneous injection of glutamate ${ }^{17)}$. However the ischemic response of RPE cells is not known. The retina is supplied with nutrients from two different vascular beds, the retinal and choroidal circulation, which supply the inner and outer layers of the retina, respectively. Experimental retinal ischemia usually only obstructs the retinal circulation, and does therefore not show the contribution of the choroidal circulation.

The present study was designed to investigate the localization of TNF- $\alpha$ immunoreactivity in rat retina affected by ischemia/reperfusion, and the relation between the expression of TNF- $\alpha$ and development of outer retinal degeneration. We used the rat four-vessel occlusion model $^{18,19)}$, because total retinal ischemia is produced and is suitable for observation of the ischemic response of both the inner and outer retina. We also investigated the effect of glutamate on TNF- $\alpha$ gene expression in cultured rat RPE cells, since high levels of glutamate may be released from retinal neurons during and after ischemia.

\section{Materials and Methods}

\section{Animals}

Adult male Sprague-Dawley rats (250 to $300 \mathrm{~g} ; \mathrm{n}=38$ ) were housed in a temperatureand light-controlled room (lights on at $06: 00$ and off at $18: 00$ ) and given food and water ad libitum. All surgical manipulations were performed under anesthesia with a mixture of nitrous oxide $(80 \%)$ and oxygen $(20 \%)$ together with halothane $(0.5 \%)$. Four-vessel occlusion was induced in animals ${ }^{18)}$. After the animals were placed in a stereotaxic frame, the vertebral arteries were electrocauterized through the alar foramina of the first cervical vertebra with an electric needle coagulator under an operating microscope. Body temperature was monitored continuously and maintained at $36-37^{\circ} \mathrm{C}$ with a heating pad. The eye balls were warmed by a heat lamp and covered with a sheet to avoid the influence of light, while both common carotid arteries were carefully clamped by neurosurgical clips for 30 minutes to prevent injury to the arteries.

To confirm whether disappearance of electroretinography (ERG) response indicates total retinal ischemia, we observed the electroretinographic response in some animals with fluorescein-dextran angiography (FAG). During the operation, we recorded ERG (TOMEY PE-2000, Tokyo, Japan). The animals were dark-adapted for 15 minutes before the recording. After the disappearance of the ERG was confirmed, phosphate-buffered saline (PBS) containing $50 \mathrm{mg}$ fluorescein-dextran with a molecular weight of 2,000,000 (Sigma, St Louis, MO, USA ; Lot No. 73H5022) was injected into the left cardiac ventricle. Eighty seconds after the injection, the rats were sacrificed and eyes were enucleated. The retina was dissected and placed in $4 \%$ paraformaldehyde in $0.1 \mathrm{M}$ phosphate buffer (PB) 
for $3 \mathrm{~h}$, flat mounted on glass slides and viewed with an inverted fluorescence microscope (Olympus BH2-RFCA, Tokyo, Japan). We recorded ERG on all animals before, during, and after the operation. The animals in which an irregular wave was observed on the ERG were excluded from the study.

\section{Immunohistochemical staining}

Three, 6 and 12 hours (each $n=5)$, and 1, 2, 4 (each $n=7$ ), and 7 days $(n=2)$ after the operation, the animals were perfusion-fixed with a mixture of $4 \%$ paraformaldehyde and $0.2 \%$ glutaraldehyde in $0.05 \mathrm{M} \mathrm{PB}$. The eyes were enucleated, then the anterior segments and vitreous body were removed. Sagittal sections of the eye cup were cut and placed in the same fixative for $1 \mathrm{~h}$.

For the light microscopic studies, the tissue sections were immersed in $0.1 \mathrm{M}$ PB containing $20 \%$ sucrose for 2 days at $4^{\circ} \mathrm{C}$. They were frozen with Tissue-Tek (Miles Inc., Elkhart, IN, USA) and cut at $10 \mu \mathrm{m}$ with a cryostat, then put on poly 1-lysine-coated glass slides. Their endogenous peroxidase activity was blocked with $0.5 \% \mathrm{H}_{2} \mathrm{O}_{2}$ for 15 min. They were incubated with $10 \%$ normal goat serum (NGS) in PBS for $1 \mathrm{~h}$ then incubated with TNF- $\alpha$ polyclonal antibody $(1: 2,000$; Genzyme, Cambridge, MA, USA) for $6 \mathrm{~h}$ at room temperature or incubated with NMDA-R1 antibody $(1: 2,000$; Chemicon International Inc., Temecula, CA, USA) for $48 \mathrm{~h}$ at $4^{\circ} \mathrm{C}$. They were washed with PBS for $15 \mathrm{~min}$, then they were incubated with biotinylated goat anti-rabbit IgG (1:200; Vector Laboratories, Burlingame, CA, USA) for $2 \mathrm{~h}$, then incubated with ABC complex (Vector Laboratories) for $1 \mathrm{~h}$. The sections incubated with TNF- $\alpha$ polyclonal antibody were developed with TrueBlue Peroxidase Substrate (Kirlegaard \& Perry Laboratories, Gaithersburg, MD, USA). The sections incubated with NMDA-R1 antibody were developed with freshly prepared diaminobenzidine-4HCl (Vectastain DAB kit, Vector Laboratories). Both were dehydrated in a graded ethanol series and placed under a coverslip with Malinol (Muto Kagaku, Tokyo, Japan).

For the electron microscopic study, vibratome sections $(40-50 \mu \mathrm{m})$ were incubated with $10 \%$ NGS in PBS for $1 \mathrm{~h}$, then incubated with TNF- $\alpha$ polyclonal antibody $(1: 4,000$; Genzyme) for $48 \mathrm{~h}$ at $4{ }^{\circ} \mathrm{C}$. They were then incubated with biotinylated goat anti-rabbit IgG ( 1 : 200 ; Vector Laboratories) for $2 \mathrm{~h}$ and immunostained with an ABC Elite kit (Vector Laboratories). They were developed with freshly prepared diaminobenzidine- $4 \mathrm{HCl}$ containing nickel (Vectastain DAB kit, Vector Laboratories) and postfixed in $1 \%$ osmium tetroxide in $0.1 \mathrm{M}$ PB for $1 \mathrm{~h}$ at $4^{\circ} \mathrm{C}$. They were dehydrated in stepped ethanol solutions and flat embedded in an Epon-Araldite mixture. Ultrathin sections were cut on a SORVAL Porter-Blum ultramicrotome and examined with a JEOL JEM-1200 EX II electron microscope (Jeol, Tokyo, Japan) with counterstaining.

To verify the specificity of staining, some sections were also incubated with non immune serum instead of the primary antiserum, incubated with the primary antiserum without the second and antisera, incubated with a primary antiserum that had been preabsorbed with its antigen.

\section{In vitro study}

Eyes were isolated from Long-Evans rats on postnatal day 5-6. They were enucleated under anesthesia by pentobarbital sodium. RPE cells were isolated as described previously ${ }^{20)}$. 
The cells were cultured in Dulbecco's modified Eagle's medium (DMEM, Gibco, N.Y, USA) with $10 \%$ fetal bovine serum (FBS, Gibco), containing antibiotics (penicillin G : 100 $\mathrm{U} / \mathrm{ml}$, streptomycin : $100 \mathrm{mg} / \mathrm{ml}$ and amphotericin $\mathrm{B}: 0.25 \mathrm{mg} / \mathrm{ml}$ ). Seven days later, cultured RPE cells were dispersed with $0.1 \%$ trypsin for $3 \mathrm{~min}$ at $37^{\circ} \mathrm{C}$. The cell suspension was centrifuged for $5 \mathrm{~min}$ at $1,000 \mathrm{rpm}$ and cells were seeded again in 6-well plates. When cells were semi-confluent, they were treated with $1.0 \mathrm{mM}$ glutamate for 4 days. The cells treated with glutamate or control cells without glutamate treatment were homogenized in $1 \mathrm{ml}$ of Isogen (Nippon Gene, Tokyo, Japan). The primers for the amplification of rat TNF- $\alpha$ and glyceraldehyde 3-phosphate dehydrogenase (GAPDH) were obtained from Clontech (Palo Alto, CA, USA). The first strand of cDNA was synthesized from $1 \mathrm{mg}$ of total RNA by reverse transcriptase using an oligo $\mathrm{d}(\mathrm{T}) 16$ primer and amplified by GeneAmp RNA PCR Core kit (Perkin-Elmer, Branchburg, NJ, USA). The amplification was performed as follows: $2 \mathrm{~min}$ at $95^{\circ} \mathrm{C}$ for initial denaturation, amplification with 30 cycles by using a step program $\left(95^{\circ} \mathrm{C}, 1 \mathrm{~min} ; 58^{\circ} \mathrm{C} 1 \mathrm{~min} ; 72^{\circ} \mathrm{C}, 1 \mathrm{~min}\right)$, followed by a final extension at $72^{\circ} \mathrm{C}$ for $7 \mathrm{~min}$. Intensity of ethidium bromide fluorescence after agarose gel electrophoresis of PCR products was measured with an MCID image analyzing system (Imaging Research Inc, St. Catharines, Ontario, Canada).

\section{Results}

\section{ERG and FAG}

Normal intact rats showed deep a waves on ERG (Fig. 1A) before the operation, and flat waves during the operation (Fig. 1B). FAG showed normal blood circulation in intact rats, and confirmed cessation of blood circulation during the operation (data not shown).

\section{Electron microscopic study}

The normal RPE cells showed round nuclei, microvilli surrounding the rod outer segments, small smooth endoplasmic reticulum (sER) and normal basal infolding (Fig. 2A). RPE cells showed an ischemic response on the 2 nd day after ischemia/reperfusion. The nuclei of RPE cells were irregular in shape, there was edema at the basal infolding area, microvilli were absent and the cisternae of the smooth endoplasmic reticulum were enlarged (Fig. 2B). RPE cells stimulated by ischemia/reperfusion contained increased numbers of phagosomes with internalized rod disks, secondary lysosomes, and lipofuscin-like granules compared to normal RPE cells (Fig. 2C).

\section{Immunohistochemistry}

NMDA-R1-like immunoreactivity was developed with DAB and was examined by light microscopy. The RPE cells in control rats showed very weak immunoreactivity (Fig. 3A), but an intense immunoreactivity appeared at $6 \mathrm{~h}$ after ischemia/reperfusion (Fig. 3B). We also examined expression of TNF- $\alpha$-like immunoreactivity in the rat retina. The control rat retina showed very weak TNF- $\alpha$ immunoreactivity (Fig. 4A), but it appeared intensely in RPE cells 2 days after ischemia/reperfusion (Fig. 4B). This immunostaining increased with the passage of time, reached a peak on the 2 nd day and decreased on the 4th day after ischemia/reperfusion (Fig. 4B, C). RPE cells were examined at the ultrastructural level to identify the subcellular localization of TNF- $\alpha$-like immunoreactivity. In RPE cells 2 days after ischemia/reperfusion, TNF- $\alpha$-like immunoreactivity was associated with enlarged sER 

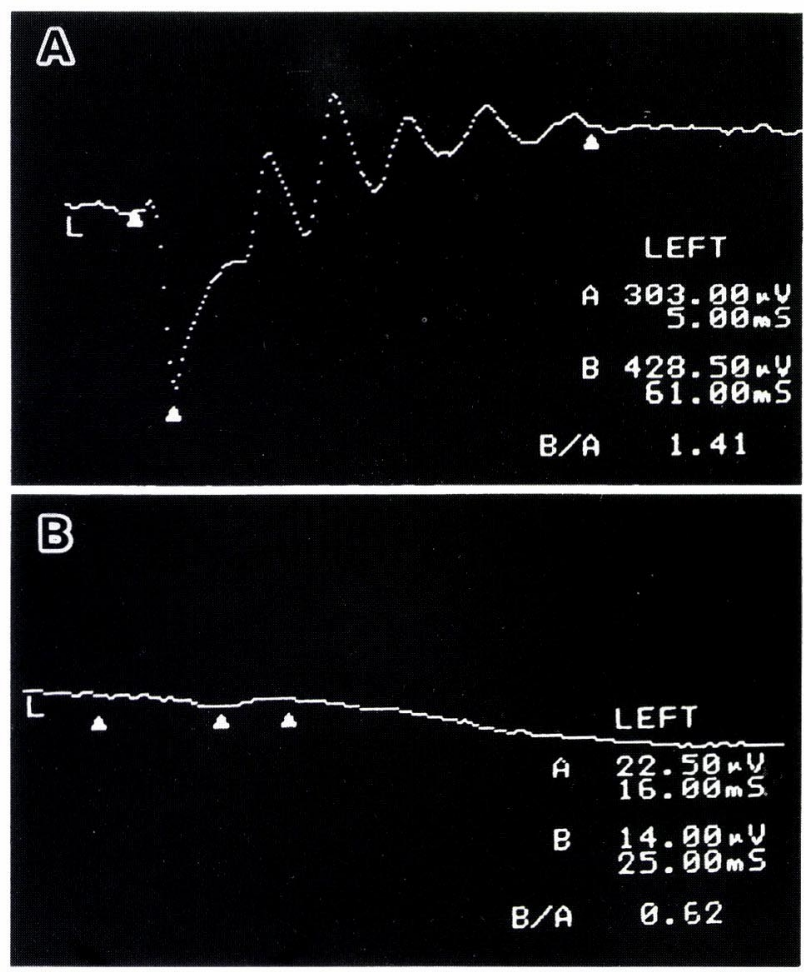

Fig. 1. ERG showing normal ERG response before the operation (A) and extinguished activity during the operation (B).

(Fig. 5A). Immunoreactivity was visible in all sER, but the intensity varied markedly. High magnification of RPE cells showed TNF- $\alpha$ immunoreactivity in small vesicles associated with the plasma membrane (Fig. 5B).

$T N F-\alpha$ mRNA expression

In RPE cells, TNF- $\alpha$ expression detected by RT-PCR was increased after the 4-day glutamate treatment (Fig. 6). The mean intensity $(n=3)$ of ethidium bromide fluorescence was $179 \%$ of that in controls. However, levels of TNF- $\alpha$ expression were not changed after treatment with the glutamate receptor antagonist MK 801 (data not shown).

\section{Discussion}

The present study showed that ischemia/reperfusion injury caused retinal degeneration not only of the sensory retina, but also of the RPE in the four-vessel occlusion model. In the sensory retina, degeneration appeared within a few days after ischemia/reperfusion injury. Cell death seemed to have occurred in the ganglion cell layer, inner plexiform layer, and inner nuclear layer (data not shown). Previous studies using high intraocular pressureinduced ischemic retina have shown several morphologically distinct types of cell death in the sensory retina, including necrosis, apoptosis and non-lysosomal vesicular cell death ${ }^{15)}$. In the outer retina, degeneration may be caused by some other mechanism. RPE cells play an 

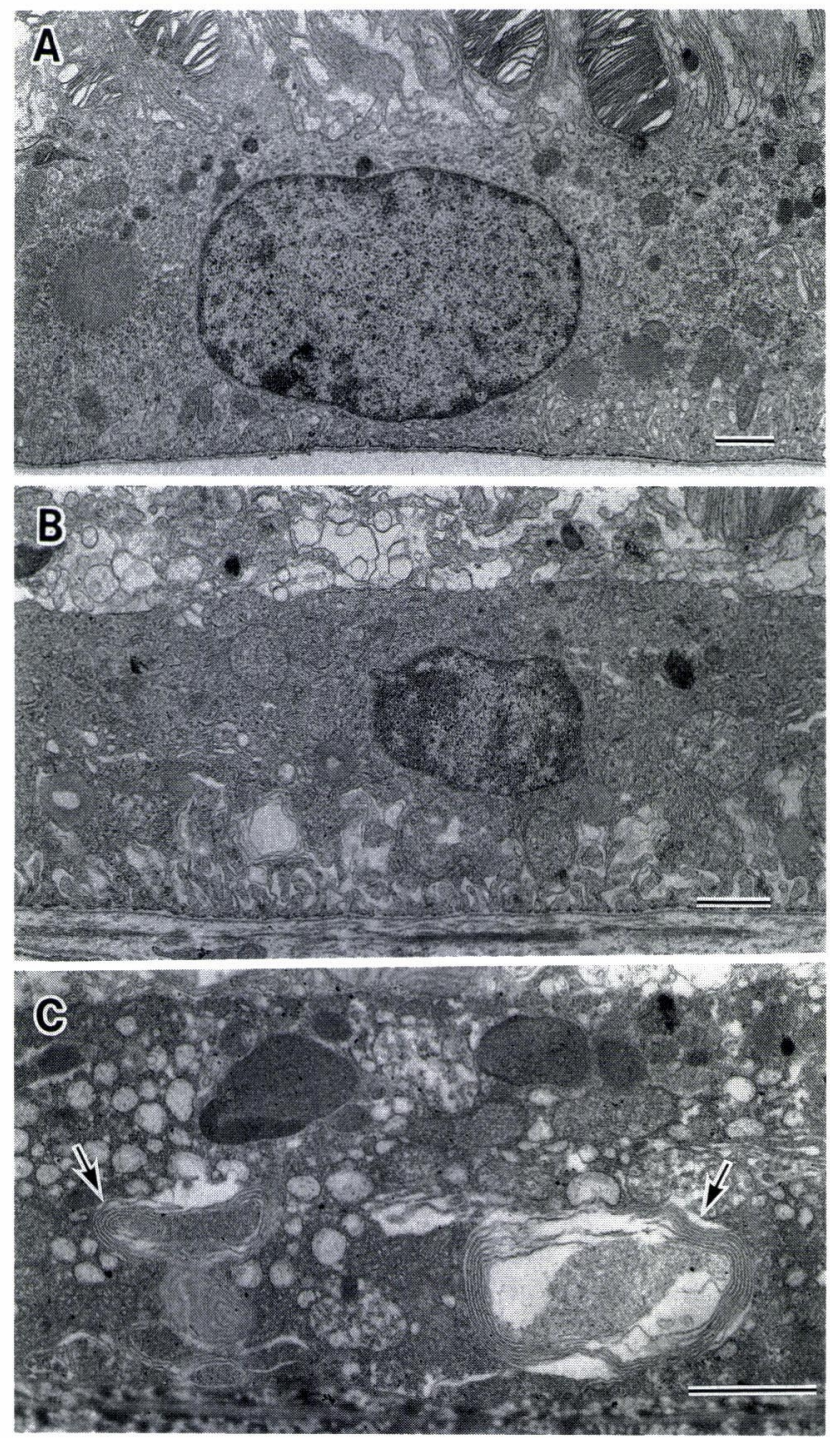

Fig. 2. Electron microscopy of the intact RPE cells (A) and the ischemic response of RPE cells on the 1st day (B) and the 2nd day (C) after ischemia/reperfusion. (B) : RPE cells showing irregularly shaped nuclei, edema in the basal infolding area, absence of the microvilli, and enlargement of the cisternae of the smooth endoplasmic reticulum. (C) : Many phagocytosed ROS are visible in the RPE cells. Bar $=1 \mathrm{~mm}$.

important role in retinal structure and have various other functions such as maintaining the blood-retinal barrier ${ }^{21)}$, shedding of rod outer segments (ROS) disks ${ }^{5)}$ and production of chemical modulators ${ }^{6-14}$. Cultured RPE cells stimulated with IL-1 $\beta$ express TNF- ${ }^{14}{ }^{14}$. Our electron microscopic study revealed that RPE cells had morphological changes in response to ischemia, including irregular-shaped nuclei and enlarged cisternae of the smooth endoplasmic reticulum. RPE cells normally phagocytize ROS in a circadian rhythm ${ }^{22}$. 

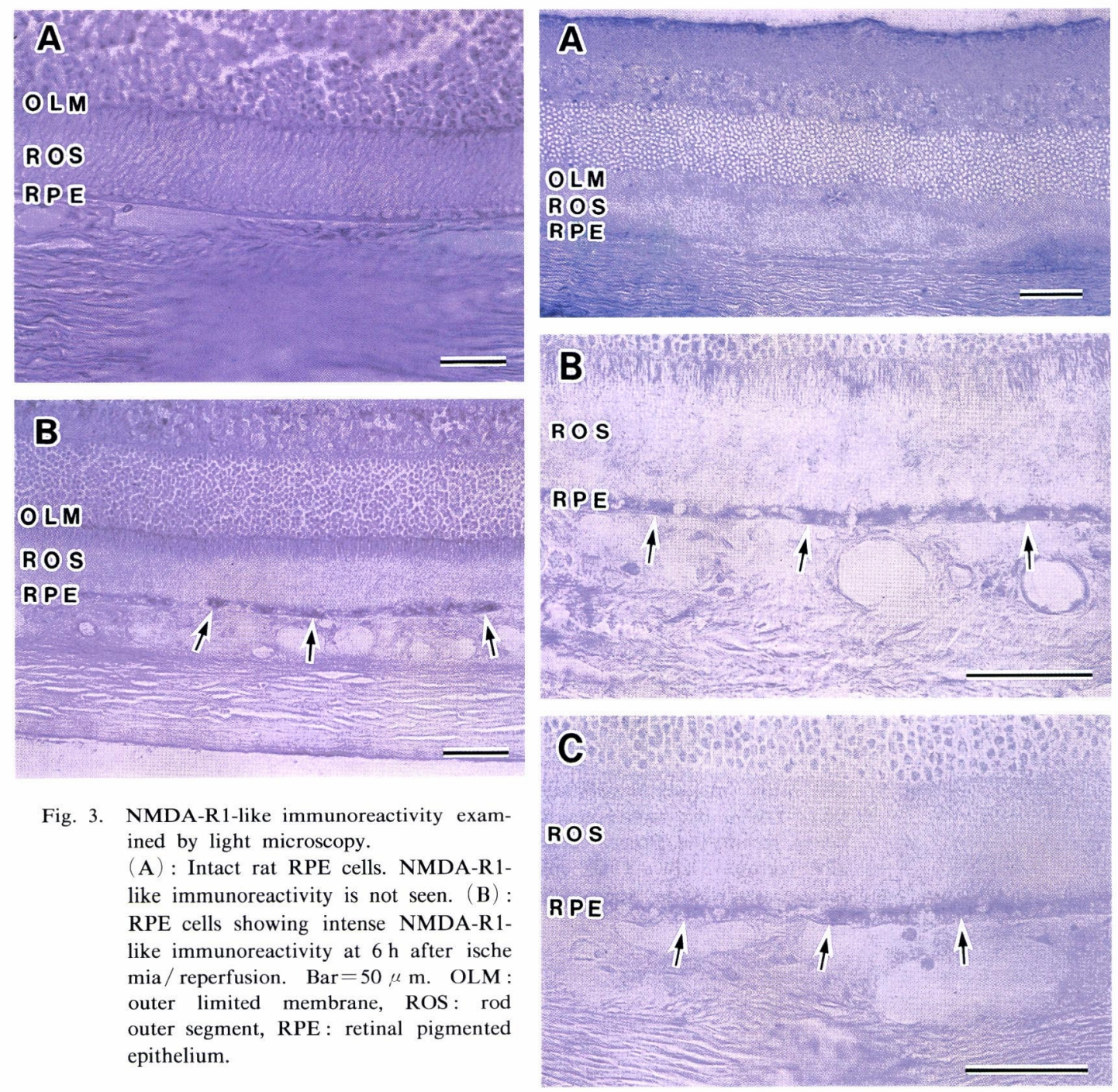

Fig. 3. NMDA-R1-like immunoreactivity examined by light microscopy.

(A) : Intact rat RPE cells. NMDA-R1like immunoreactivity is not seen. (B): RPE cells showing intense NMDA-R1like immunoreactivity at $6 \mathrm{~h}$ after ische $\mathrm{mia} /$ reperfusion. Bar $=50 \mu \mathrm{m}$. OLM : outer limited membrane, ROS: rod outer segment, RPE: retinal pigmented epithelium.

Fig. 4. TNF- $\alpha$-like immunoreactivity examined by light microscopy.

(A) : Intact rat retina showing no TNF- $\alpha$ immunoreactivity. (B) : Ischemic retina 2 days after ischemia/reperfusion. Intense TNF- $\alpha$ like immunoreactivity is visible in RPE cells. (C) : Ischemic retina 4 days after ischemia/ reperfusion. TNF- $\alpha$-like immunoreactivity is visible, but is decreased. $\mathrm{Bar}=50 \mu \mathrm{m}$. OLM : outer limited membrane, ROS : rod outer segment, RPE : retinal pigmented epithelium.

However, after ischemia/reperfusion injury, damaged RPE cells contained many phagosomes with rod disks, secondary lysosomes and lipofuscin-like granules compared to the normal RPE. These results suggest that ischemia/reperfusion injury may cause RPE cells to 

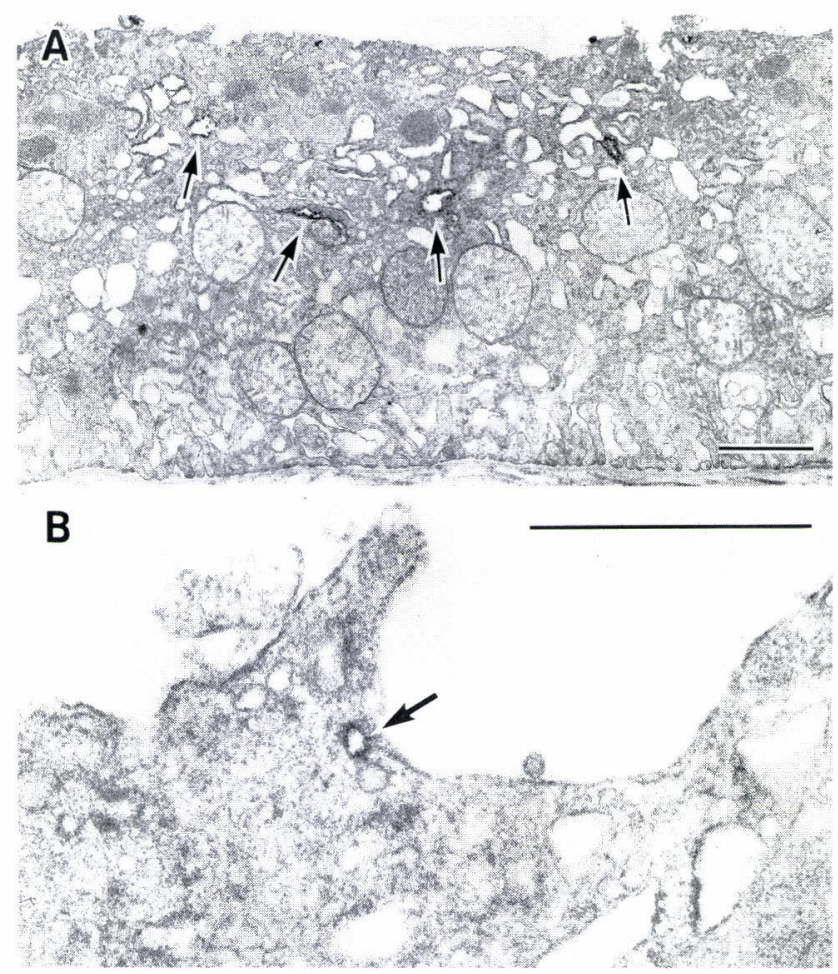

Fig. 5. TNF- $\alpha$-like immunoreactivity in RPE cells by electron microscopy. (A) : TNF- $\alpha$ like immunoreactivity in RPE cells 2 days after ischemia/reperfusion. Immunoreaction products are visible at enlarged sER (arrows). (B): High magnification showing TNF- $\alpha$ likeimmunoreactivity in small vesicles (arrow) associated with the plasma membrane. Bar $=1 \mathrm{~mm}$.

\section{Cont Glut}

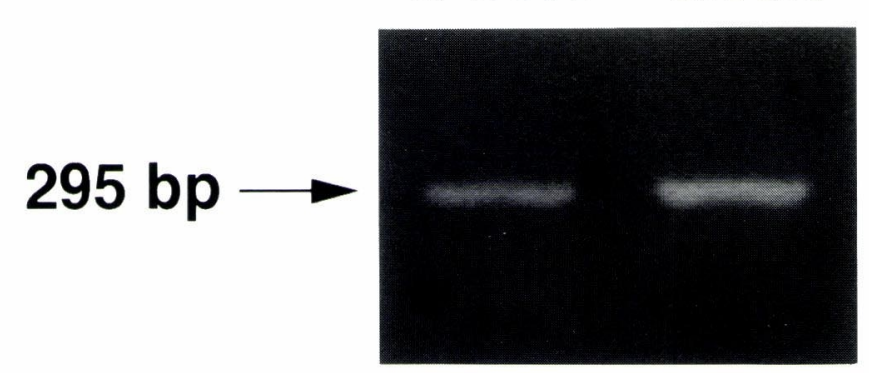

Fig. 6. RT-PCR analysis of TNF- $\alpha$ mRNA levels in RPE cells cultured with or without glutamate. TNF- $\alpha$ mRNA level was increased after glutamate treatment (Glut) as compared with the control (Cont). 
participate in activities such as protein synthesis and activation of phagocytosis of ROS. To identify the reason for retinal degeneration, we examined expression of NMDA-R1 and TNF- $\alpha$ by immunohistochemistry. Glutamate is generally thought to have a toxic effect on neurotransmitters through the NMDA-R. NMDA antagonists have a strong protective effect against permanent neuronal damage in animal models of cerebral ischemia. Ischemic neurons express newly synthesized TNF- $\alpha^{3)}$.

In the present study, TNF- $\alpha$ immunoreactivity appeared in RPE cells 1 day after reperfusion and increased with time. However the first appearance of NMDA-R1 immunoreactivity preceded that of TNF- $\alpha$. Glutamate stimulated TNF- $\alpha$ gene expression in cultured RPE cells. These results suggest that RPE cells may express NMDA-R in response to ischemic damage and that TNF- $\alpha$ may be up-regulated by glutamate via the NMDAreceptor. Elevation of intracellular calcium concentration by glutamate stimulation through the NMDA-R1 may induce TNF- $\alpha$ mRNA expression in RPE cells.

In the nervous system, TNF- $\alpha$ can induce the proliferation of astrocytes ${ }^{23)}$ and protects neurons against excitatory amino acid toxicity ${ }^{24)}$. After cerebral ischemia TNF- $\alpha$ may recruit inflammatory cells from peripheral blood into the injured tissue ${ }^{3)}$. In eye diseases, such as endotoxin-induced uveoretinitis (EIU) in rats and proliferative vitreoretinopathy (PVR), TNF- $\alpha$ has pivotal proinflammatory effects, and intraocular injection of recombinant TNF- $\alpha$ can induce acute uveoretinitis ${ }^{4)}$. EIU is characterized by breakdown of the blood-retina barrier, infiltration of the anterior segment by inflammatory cells and elevated aqueous humor and serum TNF- $\alpha$ levels. However, conflicting results have been found for TNF- $\alpha$ function in EIU. TNF- $\alpha$ gene expression was observed in the retina and iris-ciliary body during EIU ${ }^{25)}$, and inhibition of TNF- $\alpha$ activity in EIU suppressed the severity of disease. However, in another study the systemic administration of anti-TNF- $\alpha$ antibody or pentoxifylline, an inhibitor of TNF- $\alpha$ synthesis, significantly exacerbated the clinical signs of uveitis in $\mathrm{EIU}^{26)}$.

TNF- $\alpha$ may contribute to the development of inflammation after ischemia/reperfusion insult by inducing other cytokines. TNF- $\alpha$ can induce expression of cytokines, such as macrophage colony stimulating factor ${ }^{27)}$, IL- ${ }^{8)}$, and neutrophil chemotactic factor in RPE cells $^{28)}$. In ischemic damaged RPE cells, TNF- $\alpha$ may increase the expression of other inflammatory cytokines, leading to retinal degeneration. In addition, TNF- $\alpha$ may contribute to the development of outer retinal degeneration by causing RPE to up-regulate the activation of phagocytosis of ROS. TNF- $\alpha$ can enhance hydroxyl radical production in mitochondria and activity of lysosomal enzymes ${ }^{29)}$. In contrast, TNF- $\alpha$ may protect retina against the insult. TNF- $\alpha$ can stimulate RPE to produce nitric oxide ${ }^{9)}$ which decreases phagocytosis of $\operatorname{ROS}^{30)}$. TNF- $\alpha$ protects neurons by promoting the maintenance of calcium homeostasis ${ }^{24)}$, or may express neuroprotective cytokines to rescue the ischemic damaged cells.

TNF- $\alpha$ may be transported by endocrine or autocrine pathways, and act within and adjacent to RPE cells through their p55 or p75 receptors. TNF- $\alpha$ has two cell surface receptors of $55 \mathrm{kDa}(\mathrm{p} 55)$ and $75 \mathrm{kDa}(\mathrm{p} 75)^{31)}$. Their intracytoplasmic domains do not share significant homology, and they have been thought to mediate distinct cellular responses. The molecular mechanisms of p55 signaling are thought to include the activation of protein kinase $\mathrm{C}$, phospholipase $\mathrm{A} 2$, phospholipase $\mathrm{C}$, c-raf-1 kinase and sphingomyelinase $^{32-34)}$. The various bioactivities of TNF- $\alpha$ may be dependent on these complicated 
intracellular signal pathways.

We used a four-vessel occlusion model to induce high intraocular pressure-induced retinal degeneration so that we could examine the ischemic response of RPE cells. Our results suggest that TNF- $\alpha$ may be released from RPE cells after ischemic insult. TNF- $\alpha$ may play a prominent role in the development of early stage ischemia-induced retinal degeneration.

\section{Acknowledgments}

We wish to thank Dr. Donald Armstrong for critically reviewing the manuscript. This study was supported by a grant from the Japan Private School Promotion Foundation to D.O. and by grants from the Ministry of Education, Science, Sports, and Culture of Japan to S.S.

\section{References}

1) Vassalli P: The pathophysiology of tumor necrosis factors. Annu Rev Immunol, 10 : 411-452 (1992)

2) Beutler $\mathrm{B}$ and Cerami $\mathrm{A}$ : The common mediator of shock, cachexia, and tumor necrosis. Adv Immunol, 42 : 213-231 (1988)

3) Liu T, Clark RK, McDonnell PC, Young PR, White RF, Barone FC and Feuerstein GZ: Tumor necrosis factor-alpha expression in ischemic neurons. Stroke, 25 : 1481-1488 (1994)

4) Claudio L, Martiney JA and Brosnan CF : Ultrastructural studies of the blood-retina barrier after exposure to interleukin-1 beta or tumor necrosis factor-alpha. Lab Invest, 70 : 850-861 (1994)

5) Young RW and Bok D: Participation of the retinal pigment epithelium in the rod outer segment renewal process. J Cell Biol, 42 : 392-403 (1969)

6) Adamis AP, Shima DT, Yeo KT, Yeo TK, Brown LF, Berse B, D'Amore PA and Folkmanet J : Synthesis and secretion of vascular permeability factor/vascular endothelial growth factor by human retinal pigment epithelial cells. Biochem Biophys Res Commun, 193 : 631-638 (1993)

7) Campochiaro PA, Sugg R, Grotendorst $G$ and Hjelmeland LM: Retinal pigment epithelial cells produce PDGF-like proteins and secrete them into their media. Exp Eye Res, 49: 217-227 (1989)

8) Elner VM, Scales W, Elner SG, Danforth J, Kunkel SL and Strieter RM : Interleukin-6 (IL-6) gene expression and secretion by cytokine-stimulated human retinal pigment epithelial cells. Exp Eye Res, 54 : 361-368 (1992)

9) Liversidge J, Grabowski P, Ralston S, Benjamin N and Forrester JV: Rat retinal pigment epithelial cells express an inducible form of nitric oxide synthase and produce nitric oxide in response to inflammatory cytokines and activated T cells. Immunology, 83 : 404-409 (1994)

10) Martin DM, Yee D and Feldman EL: Gene expression of the insulin-like growth factors and their receptors in cultured human retinal pigment epithelial cells. Mol Brain Res, 12 : 181-186 (1992)

11) Planck SR, Huang XN, Robertson JE and Rosenbaum JT: Retinal pigment epithelial cells produce interleukin-1 beta and granulocyte-macrophage colony-stimulating factor in response to interleukin-1 alpha. Curr Eye Res, 12 : 205-212 (1993)

12) Platts KE, Benson MT, Rennie IG, Sharrard RM and Rees RC: Cytokine modulation of adhesion molecule expression on human retinal pigment epithelial cells. Invest Ophthalmol Vis Sci, 36 : 2262-2269 (1995)

13) Schweigerer L, Malerstein B, Neufeld G and Gospodarowicz D: Basic fibroblast growth factor is synthesized in cultured retinal pigment epithelial cells. Biochem Biophys Res Commun, 143 : 934-940 (1987)

14) Tanihara $H$, Yoshida $M$ and Yoshimura $N$ : Tumor necrosis factor-alpha gene is expressed in stimulated retinal pigment epithelial cells in culture. Biochem Biophys Res Commun, 187 : 1029-34 (1992)

15) Buchi ER : Cell death in rat retina after pressure-induced ischaemia-reperfusion insult : electron microscopic study. II. Outer nuclear layer. Jpn J Ophthalmol, $36: 62-68$ (1992)

16) Weber M, Bonaventure $\mathbf{N}$ and Sahel JA : Protective role of excitatory amino acid antagonists in experimental retinal ischemia. Graefes Arch Clin Exp Ophthalmol, 233 : 360-365 (1995)

17) Lucas $D$ and Newhouse $J$ : The toxic effect of sodium L-glutamate on the inner layer of the retina. Arch Ophthalmol, 58 : 193-201 (1957)

18) Pulsinelli WA and Brierley JB : A new model of bilateral hemispheric ischemia in the unanesthetized rat. Stroke, $10: 267-272$ (1979)

19) Armstrong D, Stockton R, Wenganack T, Browne R, Stadler S and Dunlap W : Vulnerability of retina to global forebrain ischemia in the rat four-vessel occlusion (4-vo) model of transient cerebral ischemia. Invest Ophthalmol Vis Sci, 34 : 3612-3619 (1993)

20) Uchida N, Kiuchi $Y$, Miyamoto K, Tobe T, Tomita M, Shioda S, Nakai $Y$ and Oguchi K : Glutamatestimulated proliferation of rat retinal pigment epithelial cells. Eur J Pharmacol, 343 : 265-273 (1998) 
21) Fine BS: Limiting membranes of the sensory retina and pigment epithelium. Arch Ophthalmol, $66: 847-860$ (1961)

22) La Vail MM: Rod outer segment disk shedding in rat retina relationship to cyclic lighting. Science, 194 : 1071-1074 (1976)

23) Selmaj KW, Farooq M, Norton WT, Raine CS and Brosnan CF: Proliferation of astrocytes in vitro in response to cytokines. A primary role for tumor necrosis factor. J Immunol, 144 : 129-135 (1990)

24) Cheng B, Christakos S and Mattson MP: Tumor necrosis factors protect neurons against metabolic-excitotoxic insults and promote maintenance of calcium homeostasis. Neuron, 12 : 139-153 (1994)

25) Planck SR, Huang XN, Robertson JE and Rosenbaum JT : Cytokine mRNA levels in rat ocular tissues after systemic endotoxin treatment. Invest Ophthalmol Vis Sci, 35 : 924-930 (1994)

26) De-Vos AF, Van-Haren MA, Verhagen C, Hoekzema R and Kijlstra A : Systemic anti-tumor necrosis factor antibody treatment exacerbates endotoxin-induced uveitis in the rat. Exp Eye Res, 61:667-675 (1995)

27) Jaffe GJ, Van-Le L, Valea F, Haskill S, Roberts W, Arend WP, Stuart A and Peters WP: Expression of interleukin-1 alpha, interleukin-1 beta, and an interleukin-1 receptor antagonist in human retinal pigment epithelial cells. Exp Eye Res, 55 : 325-335 (1992)

28) Elner VM, Strieter RM, Elner SG, Baggiolini M, Lindley I and Kunkel SL: Neutrophil chemotactic factor (IL-8) gene expression by cytokine-treated retinal pigment epithelial cells. Am J Pathol, 136 : 745-750 (1990)

29) Watanabe N, Yamauchi N, Neda H, Maeda M, Tsuji Y, Okamoto T, Akiyama S, Sasaki H, Tsuji N and Niitsuet $\mathrm{Y}$ : Enhancement of lysosomal enzyme activity by recombinant human tumor necrosis factor and its role in tumor cell killing in vitro. Jpn J Cancer Res, 83 : 638-643 (1992)

30) Becquet F, Courtois $Y$ and Goureau $O$ : Nitric oxide decreases in vitro phagocytosis of photoreceptor outer segments by bovine retinal pigmented epithelial cells. J Cell Physiol, 159 : 256-262 (1994)

31) Tartaglia LA and Goeddel DV : Two TNF receptors. Immunol Today, 13 : 151-153 (1992)

32) Kolesnick R and Glove DW : The sphingomyelin pathway in tumor necrosis factor and interleukin-1 signaling. Cell, 77 : 325-328 (1994)

33) Yao B, Zhang Y, Delikat S, Mathias S, Basu S and Kolesnick R: Phosphorylation of Raf by ceramideactivated protein kinase. Nature, $378: 307-310$ (1995)

34) Wiegmann K, Schtze S, Kampen E, Himmler A, Machleidt T and Krnke M: Human 55-kDa receptor for tumor necrosis factor coupled to signal transduction cascades. J Biol Chem, 267 : 17997-18001 (1992)

[Received January 21, 1999 : Accepted February 1, 1999] 